\section{Safety and efficacy of nimodipine in resuscitation of patients outside hospital}

The extent of brain injury after cardiac arrest depends not only on the duration of the arrest but also on the time taken until the circulation is fully restored. Postischaemic hypoperfusion may contribute to brain damage after cerebral ischaemia, ${ }^{1}$ and there is no treatment to protect the brain against anoxic-ischaemic injury. histopathological findings in primates in a study resembling resuscitation in man. ${ }^{3}$ The authors recommended controlled clinical trials in patients resuscitated after cardiac arrest.

Our study provides the first human data on safety and efficacy of $\mathbb{D}$ nimodipine in cerebral resuscitation outside hospital. The treatment was well tolerated, and the results suggest that there may be more survivors when nimodipine is used. We have started a randomised double blind clinical trial to investigate the use of nimodipine in resuscitation from cardiac arrest outside hospital.

This study was supported by the Paavo Nurmi Foundation, Finland.

Outcome in patients resuscitated after cardiac arrest outside hospital

\begin{tabular}{|c|c|c|c|c|c|c|}
\hline & \multicolumn{3}{|c|}{ Group treated with nimodipine } & \multicolumn{3}{|c|}{ Controls } \\
\hline & $\underset{(n=22)}{\text { All }}$ & $\begin{array}{c}\text { Patients with } \\
\text { ventricular fbrillation } \\
(\mathrm{n}=19)\end{array}$ & $\begin{array}{c}\text { Patients given } \\
\text { bolus dose } \\
(\mathrm{n}=11)\end{array}$ & $\underset{(n=22)}{\text { All }}$ & $\begin{array}{l}\text { Of patients with } \\
\text { ventricular fibrillation } \\
(n=19)\end{array}$ & $\begin{array}{l}\text { Of patients } \\
\text { given bolus dose } \\
(\mathrm{n}=11)\end{array}$ \\
\hline $\begin{array}{l}\text { No who survived } \\
\text { Normal consciousness at } 24 \mathrm{~h} \\
\text { Discharged home }\end{array}$ & $\begin{array}{l}14^{\star} \\
13 \\
12\end{array}$ & $\begin{array}{l}14^{\star \star} \\
13^{\star} \\
12^{\star}\end{array}$ & $\begin{array}{l}9 * \\
7 * \\
7\end{array}$ & $\begin{array}{l}7 \\
7 \\
7\end{array}$ & $\begin{array}{l}5 \\
5 \\
5\end{array}$ & $\begin{array}{l}4 \\
2 \\
3\end{array}$ \\
\hline
\end{tabular}

${ }^{\star} \mathrm{p}<0.05$ for difference between treated group and controls; ${ }^{\star \star} \mathrm{p}<0.01$.

We investigated the safety and efficacy of the calcium entry blocker nimodipine in cardiopulmonary resuscitation after cardiac arrest due to ventricular fibrillation outside hospital.

\section{Patients, methods, and results}

The group treated with nimodipine consisted of 22 patients with arrhythmias and the control group of matched historical controls with arrhythmias resuscitated one year earlier by the mobile intensive care unit in Helsinki. Age and sex distribution and characteristics of cardiac arrest were similar in both groups. Nimodipine was given to the first six patients in increasing doses of $0 \cdot 125-0.5 \mu \mathrm{g} / \mathrm{kg}$ body weight/minute for 24 hours. The next five patients received a continuous infusion of $0.5 \mu \mathrm{g} / \mathrm{kg}$ body weight/minute for 24 hours. The remaining 11 patients received a bolus dose of $10 \mu \mathrm{g} / \mathrm{kg}$ body weight in one minute within 30 minutes of cardiac arrest, immediately followed by a continuous infusion of $0.5 \mu \mathrm{g}$ nimodipine $/ \mathrm{kg} /$ minute for 24 hours. Fisher's exact test was used for statistical comparisons.

The table shows that there were more survivors in the whole nimodipine group (including three patients with primary pulseless rhythms other than ventricular fibrillation) $(p<0.05)$ and in the nimodipine group with true ventricular fibrillation $(p<0 \cdot 01)$. All patients with pulseless rhythms (electromechanical dissociation or slow ventricular rhythm) died. More patients in the true ventricular fibrillation group receiving nimodipine recovered normal consciousness within 24 hours than in the control group $(p<0.05)$. More patients with ventricular fibrillation who received nimodipine were discharged home than controls $(p<0.05)$.

No serious side effects were detected. After the bolus injection three patients showed a transient drop of $40 \mathrm{~mm} \mathrm{Hg}$ in mean arterial pressure lasting less than two minutes. One patient showed facial flushing during infusion of $0.5 \mu \mathrm{g}$ nimodipine $/ \mathbf{k g} /$ minute.

\section{Comment}

Animal studies suggest that calcium entry blockers may be effective in patients with cerebral ischaemia. ${ }^{23}$ There are no previous human studies of nimodipine or any prospective studies of other calcium blocking drugs in cerebral resuscitation. Calcium entry blockers have several possible mechanisms of beneficial action in patients with neuronal anoxia. ${ }^{1}$ Calcium is suggested to be the final common pathway in ischaemic cell death, ${ }^{4}$ and calcium entry blockers may inhibit calcium influx into ischaemic neurons, producing a cytoprotective effect. Another mechanism may be their ability to prevent the postischaemic hypoperfusion after global ischaemia. Many of the calcium entry blockers seem to have a cerebroprotective effect when given before global ischaemia. The beneficial effect on neurological recovery in animals has been documented for nimodipine and lidoflazine when given after global ischaemia. ${ }^{3}$ Nimodipine reduces reperfusion impairment after global ischaemia in cats and dogs, as does flunarizine in dogs. ${ }^{2}$ Nimodipine is one of the most potent inhibitors of cerebral vasospasm but is less likely to cause peripheral vasodilatation and hypotonia. ${ }^{5}$ Steen et al recently reported that intravenous nimodipine treatment improved neurological outcome and
1 Siesjö BK. Cell damage in the brain: a speculative hypothesis. $f$ Cereb Blood Flow Metab 1981;1:155-86

2 Kazda S, Hoffmeister F, Garthoff B, Towart R. Prevention of the postischaemic impaired reperfusion of the brain by nimodipine. Acta Neurol Scand 1979;60(suppl 72):302-3.

3 Steen PA, Gisvold SE, Milde JH, et al. Nimodipine improves outcome when given after complete cerebral ischemia in primates. Anesthesiology 1985;62:406-14.

4 Schanne FAX, Kane AB, Young EE, Farber JL. Calcium dependence of toxic cell death: a final common pathway. Science 1979:206:700-3.

5 Mohamed AA, McCulloch J, Mendelow AD, Teasdale GM, Harper AM. Effect of the calcium antagonist nimodipine on local cerebral blood flow: relationship to arterial blood pressure. I Cereb Blood Flow Metab 1984;4:206-11.

(Accepted 18 September 1986)

University of Helsinki, SF 00290 Helsinki, Finland

RISTO O ROINE, MD, resident in neurology

MARKKU KASTE, MD, PHD, senior lecturer in neurology

ARI KINNUNEN, $M D$, chief doctor of mobile intensive care unit

PERTTI NIKKI, MD, PHD, chief doctor of intensive care unit

Correspondence to: Dr Roine.

\section{Poverty and teenage pregnancy}

Maternal and child welfare has long been a cause for concern, and particular attention has recently been focused on teenage mothers. ${ }^{1}$ In Britain although the number of babies born to teenage mothers aged 15-19 decreased from 96109 in 1966 to 60750 in 1984, the number of illegitimate babies born to mothers in this age group has increased from $22305(23.2 \%)$ to 36544 $(60 \%),{ }^{2}{ }^{3}$ yet virtually no routinely collected information about the socioeconomic circumstances of this group is available. We present data relating to nulliparous teenage women collected as part of a detailed study of the provision of antenatal care in the east end of Glasgow.

\section{Subjects, methods, and results}

Our sample consisted of 911 nulliparous women, including 283 teenagers, who booked for delivery at Glasgow Royal Maternity Hospital between February 1984 and May 1985 and who lived in the east end of Glasgow. Information about the women's demographic and socioeconomic characteristics was included in a questionnaire administered by midwives at antenatal clinics.

The table shows that single parenthood, unemployment, and reliance on state benefits were high among all nulliparous women but increasingly so in younger women. Forty two per cent of all the women studied were wholly reliant on state benefits, but this figure rose to $71 \%$ for women aged less than 20 . Of all the employed teenage women, $59 \%$ said that their income was adequate, compared with only $32 \%$ of those receiving state benefits. 


\begin{tabular}{|c|c|c|c|c|c|c|c|c|}
\hline & \multicolumn{8}{|c|}{ Age (years) } \\
\hline & $\begin{array}{c}16 \\
(n=32)\end{array}$ & $\begin{array}{c}17 \\
(n=64)\end{array}$ & $\begin{array}{c}18 \\
(n=85)\end{array}$ & $\begin{array}{c}19 \\
(n=102)\end{array}$ & $\begin{array}{c}20-24 \\
(n=392)\end{array}$ & $\begin{array}{c}25-29 \\
(n=174)\end{array}$ & $\begin{array}{c}30+ \\
(n=53)\end{array}$ & $\begin{array}{c}\text { All ages } \\
(n=911)^{\star}\end{array}$ \\
\hline \multicolumn{9}{|l|}{ Marital state: } \\
\hline Single & 84 & 58 & 55 & 52 & 28 & 17 & 13 & 35 \\
\hline Married & 0 & 16 & 212 & 27 & 56 & 68 & 74 & 48 \\
\hline Stable relationship & 6 & 5 & 5 & 8 & 6 & 6 & 4 & 6 \\
\hline Getting married & 6 & 22 & 19 & 14 & 10 & 5 & 2 & 10 \\
\hline \multicolumn{9}{|l|}{ Educational attainment: } \\
\hline Left school at or before minimum leaving age & 100 & 97 & 93 & 88 & 90 & 78 & 70 & 88 \\
\hline \multicolumn{9}{|l|}{ Income sources: } \\
\hline Receiving only state benefits & 78 & 75 & 80 & 58 & 33 & 20 & 21 & 42 \\
\hline \multicolumn{9}{|l|}{ Wages: } \\
\hline Woman's only & 16 & 14 & 8 & 17 & 13 & 9 & 2 & 12 \\
\hline Partner's only & 0 & 3 & 2 & 7 & 12 & 12 & 21 & 10 \\
\hline Woman and partner & 0 & 6 & 5 & 12 & 34 & 48 & 51 & 29 \\
\hline \multicolumn{9}{|l|}{ Employment state: } \\
\hline \multicolumn{9}{|l|}{ Women: } \\
\hline Full timet & 16 & 19 & 12 & 26 & 44 & 55 & 50 & 38 \\
\hline Stopped during pregnancy & 16 & 19 & 13 & 12 & 16 & 16 & 17 & 16 \\
\hline No of partners: & 21 & 46 & 70 & 87 & 355 & 160 & 52 & 798 \\
\hline Of which, $\%$ full time & 14 & 26 & 14 & 45 & 60 & 76 & 83 & 56 \\
\hline Of which, $\%$ unemployed & 81 & 70 & 81 & 53 & 37 & 22 & 15 & 41 \\
\hline
\end{tabular}

^Age unknown for nine women.

tAt time of interview.

\section{Comment}

Part of the current concern about teenage pregnancy is associated with the rise in illegitimacy, and, although it has been pointed out that this should not necessarily be equated with single motherhood per se, $70 \%$ of the unmarried 17-19 year olds in our survey described themselves as single-that is, neither planning to marry nor living in a stable relationship.

The shortage of jobs means that most teenage women depend on state benefits, but are they adequate? A mother aged 18 years or over with one child and living with her parents is currently entitled to a long term weekly benefit of 133.45 ; if she lives in her own home overall weekly benefit rises to only $£ 41 \cdot 10$. Thus after an estimated average expenditure on food has been allowed for, ${ }^{4} £ 20-25$ is left to cover all weekly household and personal expenses, including fuel, clothing, shoes, travel, and recreation for the mother and her child. In view of these income levels and proposed changes in social security benefits it is not surprising that poverty affects many teenage mothers and their children.

Nearly 20 years ago Townsend illustrated the range and extent of poverty in the United Kingdom using a series of case descriptions, one of which was of a single teenage mother living in Glasgow. ${ }^{5}$ What is perhaps most disturbing about the current economic position of teenage mothers is that so little seems to have changed since Townsend's survey in 1968. If poverty does influence the health of women and their children inequalities in health will persist as long as such disadvantage continues.

We thank the midwives and clerical staff at Glasgow Royal Maternity Hospital and our colleagues at the Social Paediatric and Obstetric Research Unit for help and advice. The Social Paediatric and Obstetric Research Unit is supported by a grant from the Scottish Home and Health Department and the Greater Glasgow Health Board.

1 Simms M, Smith C. Teenage mothers and their partners. A survey in England and Wales. London: HMSO, 1986.

2 Office of Population Censuses and Surveys. Birth statistics England and Wales. London: HMSO, 1974, 1975.

3 Registrar General Scotland. Annual report. Edinburgh: HMSO, 1971-85.

4 Durward L. Poverty in pregnancy: the cost of an adequate diet for expectant mothers. London: Maternity Alliance, 1984.

5 Townsend P. Poverty in the United Kingdom: a survey of household resources and standards of living. Harmondsworth: Penguin Books, 1979.

(Accepted 23 September 1986)

Social Paediatric and Obstetric Research Unit, University of Glasgow, Glasgow G12 8LS

SUSAN WILLIAMS, SRN, SCM, research assistant

JOHN F FORBES, BA, MSC, health economist

Department of Community Medicine, Glasgow Royal Maternity Hospital, Glasgow G4 0NA

GILLIAN M MCILWAINE, MD, PHD, specialist in community medicine

Department of Information Services, Greater Glasgow Health Board, Glasgow G2 4JT

KATHRYN ROSENBERG, BA, PHD, epidemiologist

Correspondence to: Ms Williams.

\section{Campylobacter enteritis in young children living in households with puppies}

Animals may be implicated in the spread of campylobacter enteritis infection to man $^{1}$; in particular, dogs suffering from diarrhoea have been cited as a likely cause of infection. ${ }^{2}$ Most canine campylobacter infections occur in young asymptomatic dogs. ${ }^{3}$

We studied the possible association between campylobacter enteritis infection in children aged $0-5$ and the presence of a young dog in the household.

\section{Patients, methods, and results}

Although campylobacter infection is not a statutorily notifiable disease, all cases identified in Darlington are notified to the department of community medicine. In addition, all faecal samples for analysis of "food poisoning" and diarrhoeal illness are tested in the local laboratory and thus a comprehensive record of campylobacter infection in the district is available. After receipt of the campylobacter notification the environmental health officers undertake a detailed, standardised inquiry of cases and contacts. We analysed such inquiry reports of campylobacter notifications for the years 1984 and 1985 retrospectively. A case-control study was undertaken among children aged from 0 to 5 to test the hypothesis that puppies are a major contributory factor in childhood campylobacter infections. To obtain controls all health visitors recorded the age, sex, and details of any household pets of five consecutive children aged from 0 to 5 . A dog was classed as a puppy at the discretion of the health visitor.

Eighty two cases of campylobacter infection were notified. Interviews led to seven further positive identifications out of 169 household contacts identified (4\%). Of the 89 patients, 48 were boys and 41 were girls $(1 \cdot 17: 1)$. The notification rate was highest for children aged from 0 to 5 , at $1 \cdot 1 / 1000$ a year. Symptomatology was available for $62(70 \%)$ of the cases. The principal symptoms recorded in these cases were diarrhoea $(58(95 \%))$, abdominal pain $(45(73 \%))$, and vomiting (16 $(26 \%))$. The average duration of symptoms was eight days.

The distribution of pets showed that nine $(60 \%)$ of the patients and $48(43 \%)$ of the controls had an adult dog or puppy in the household, and a significant association was found between cases of campylobacter infection in the 0-5 year age group and the presence of a puppy (table)

Number (\%) of cases and controls with and without puppy in household

\begin{tabular}{lcc}
\hline & Puppy in household & No puppy in household \\
\hline Cases & $6(46)$ & $9(10)$ \\
Controls & $7(54)$ & $83(90)$ \\
\hline
\end{tabular}

$\chi^{2}$ with Yates's correction $=9 \cdot 49,1 \mathrm{df}, 0.01>p>0.001$

\section{Comment}

The case-control study showed a significant association between cases of campylobacter infection in the 0-5 year age group and the presence of a puppy in the household. Puppies have been shown to have a high rate of carriage of campylobacter, and transmission to man may occur. ${ }^{3}{ }^{4}$ This study 